Ambient Science, 2021: Vol. 08(Sp1); 24-29

DOI:10.21276/ambi.2021.08.sp1.ta04

\title{
Examining the Mental Toughness Levels of Young Football Players
}

\author{
Mahmut Kurtay $^{* 1}$, Tahir Kilic ${ }^{2}$ \\ University, Turkey \\ Study Area: Balikesir, Turkey \\ Coordinates: $39^{\circ} 30^{\prime} \mathrm{N} ; 26^{\circ} 30^{\prime} \mathrm{E}$
}

${ }^{1}$ Department of Physical Education and Sport Education, Institute of Health Sciences Manisa Celal Bayar University, Turkey

${ }^{2}$ Department of Physical Education and Sport Education, Akdeniz

Key words: Forest Litter, Solar Radiation, Infiltration

\section{Abstract}

Following the screening model 431 players, who were playing at the development leagues selected for this study. To collect the data one-on-one interviews from the participant football players were taken. The personal information form and the Sports Mental Toughness Questionnaire (SMTQ) were used as research tools. As a result, there was a statistically significant difference concerning the control sub-dimension of the mental toughness for the league and championship experience variables was evidenced. Following the club variable, a statistically significant difference between the general mean scores of the mental toughness and control/ continuity sub-dimensions of mental toughness was found. As per the position variable, no significant difference was observed in mental toughness levels.

(Garmezy, 1991; Luthar et al., 2000; Masten, 2001; Werner, 1995). Additionally, it is an accepted fact that in order to display high performance in today's sports settings psychological competence as well as the physical competence of the player is important (Jackson et al., 2001). We can encounter numerous definitions of mental toughness in research studies. At first sight, mental toughness is considered a personal trait, which decreases the negative effects of stress and supports compatibility (Jacelon, 1997). From this point of view, some studies focus on genetic characteristics, suggesting that some people are born with endurance (Block \& Block, 1980). However, previous studies revealed that mental toughness is a personal trait that can be learned (Beardslee \& Podorefsky, 1998). At this point, mental toughness becomes a learnable and developmental phenomenon that can be realized in the face of the realities (Masten et al., 1990). The researchers explain mental toughness as recovery after adversities and failures and coping with them (Clough et al., 2002; Goldberg, 1998; Jones et al., 2002), effectively coping with pressure and difficulties (Clough et al., 2002; Jones et al., 2002; Loehr, 1995; Williams, 1988), racing with oneself and others (Bull et al., 2005; Clough et al., 2002), pertinaciousness and tenacity (Goldberg, 1998; Gould et al., 1987), developing over pressure (Bull et al., 2005; Jones et al., 2002; Thelwell et al., 2005), being flexible or emotionless over bad situations (Bull et al., 2005; Clough et al., 2002; Goldberg, 1998), having a resolution for controlling one's future (Clough et al., 2002; Jones et al., 2002), or having high mental skills (Bull et al., 1996; Golby

*Corresponding Author: tkilic@akdeniz.edu.tr 
et al., 2003; Loehr, 1995). In other words, mental toughness is to break the pressure effectively, psychological strength, the ability to keep the concentration high, have a high level of resolution, and having an unshakable personality (Crust, 2008; Connaughton et al., 2008; Gucciardi, 2012; Perry et al., 2002; Sheard, 2013). Psychological tensions and situations creating pressure in sports games necessitate the players to sustain their psychology and to cope with the difficult situations. As per the strength of the player to cope with difficulties, it necessitates mental toughness (Dogan, 2015). Besides, mental toughness also stands for the psychological capacity that supports the recovery of an individual in cases of increased responsibility, mishap, failure, and conflict (Luthans, 2002). When the daily lives of people are examined, it is observed that the individuals with a high level of mental toughness have a more positive view of life, they hold on to life with more passion, and they turn sudden negativities they face into opportunities. As per the individuals with a low level of mental toughness, they have an external locus of control and they cannot resist the change (Maddi \& Khoshaba, 1994; Klag \& Bradley, 2004). Considering the positive effect of mental toughness in the life of an individual, it has been a research topic on how an individual acquires this feature or whether it exists in his/her personality. Therefore, while some researchers suggest that mental toughness exists within the personality of an individual based on his/her genetic characteristics (Block \& Block, 1980), some others assert that mental toughness is a learnable personality feature (Beardslee \& Podorefsky, 1998). Jones et al., (2002), provided the first informational data by following a qualitative approach concerning the elements that comprise mental toughness. These elements are as follows: motivation, coping with pressure, self-confidence, and concentration structures. Jones et al., (2007), determined that these features of mental toughness are used before the contest (for example: determining the goal), during the contest (for an instant: coping with pressure), and after the contest (for example: managing the failure). Rather than using a more qualitative approach, Clough et al., (2002), defined mental toughness with the ${ }_{4} \mathrm{C}$ model. These are: 1- Control: managing numerous issues at one time, remaining effective more than being under control. 2- Commitment: strictly dealing with the goals rather than the difficulties. 3- Challenge: perceiving potential threats as an opportunity for personal development and improving in settings of perpetual change. 4- Confidence: sustaining self-belief against regressions. Harmison (2011) perceived mental toughness as the interaction between an individual and his/her environment. In fact, the individual and his/her perceptions concerning the situation determine whether the individual behaves mentally tough or not. For example, a player may perceive the championship game as a stress factor, while another may comprehend the same case as an opportunity. Concerning how mental toughness is formed, other researchers determined that players attributed their mental toughness to "caught" factors (unintentional mental toughness behaviors). These factors are: sibling rivalry, coach expectations, family support, hard exercises, motivational training settings, encouraging the teammates, and coping with life (Connaughton et al., 2011; Connaughton et al., 2010). Detecting the importance of mental toughness in sports caused an increase in the number of studies on sports as well.

\section{Materials and methods:}

A total of 431 football players participated in the research actively playing at the U-14, U-15, U-16, U-17 and U-19 development leagues of the TM Akhisarspor, Altay, Balýkesirspor Baltok, Grand Medical Manisaspor and Manisa Büyüksepir Belediyespor football teams

Scanning models were the research approaches aiming at describing an existing situation or a situation in the past. The issue, the individual, or the object, which were subject to research, was attempted to be described as was and under its conditions (Karasar, 2005).

Sports mental toughness questionnaire (SMTQ): being comprised of 14 articles, the "Sports Mental Toughness Questionnaire" (SMTQ) was developed by Sheard et al., (2009), to determine the mental toughness levels in sports settings. Having three sub-dimensions (Confidence, Continuity, Control) besides the general mental toughness, the scale is four-point Likert style ( $1=$ Definitely False; 4= Definitely True). The explanations for the three sub-dimensions of the Sports Mental Toughness Questionnaire are presented below (Sheard et al., 2009; Sheard, 2013). Confidence: Belief in one's skills for reaching the goal and thinking oneself better than the rivals in difficult cases that necessitate struggle (Article 1,5,6,11,13,14). Control: Keeping one's calm, being restrained and comfortable under stress and in unexpected cases (Article 2,4,7,9). Continuity: Taking responsibility, keeping concentration, and struggling for the determined goals (Article 3,8,10,12). Turkish adaptation studies of the Sports Mental Toughness Questionnaire (SMTQ) were conducted by Sheard et al. (2009); Sheard (2013). These results show that the scale is reliable (Sheard et al., 2009; Sheard, 2013). In our study, the Cronbach Alpha coefficient of the Scale was determined as 0.74 .

Data collection tools: after receiving necessary permissions from the Ethics Committee of the University, official permissions were gained from the football teams, which the research was conducted on, via the Graduate School of Health Sciences. The data were collected by the researcher via one-on-one interviews with the football players living in different provinces and playing at Development Leagues in U-14, U-15, U-16, U-17, U-19 age groups. The trainers of the football teams of the research 
TECHNOSCIENCE ARTICLE

and youth setup coaches were contacted and the teams were reached at the predetermined time. The participant teams got ready at the meeting room of the youth setup facilities just half an hour before the training started, necessary explanations were made regarding the research study, and verbal consents of the volunteering participants were gained before starting the study. Additionally, parent consent forms were received from the participant below the age of 18. The questionnaire forms gathered by the researcher were checked and the ones with mistakes or missing information were excluded from the research. Subsequently, the valid and acceptable ones were transferred into the computer environment after being analyzed by the SPSS 20 package program. Descriptive statistics such as arithmetic mean, standard deviation, and frequency/percentage were used to test the hypotheses of the research. One-way variance (ANOVA) analysis was used in the comparison of three or more groups, and a t-test was used in the comparison of two groups. At the end of the ANOVA analysis, to detect the source group of significant difference, the Tukey HSD test was used for the homogeneous distribution of the variances, and the Tamhane test was used for the non-homogeneous distribution of the variances. The significance level was accepted as $\mathrm{p}<0.05$.

\section{Results:}

Table-1: ANOVA test results of mental toughness levels based on League variable

\begin{tabular}{|c|c|c|c|c|}
\hline \multicolumn{5}{|c|}{ Mental toughness levels } \\
\hline Groups & Sum of Squares & df & \multicolumn{2}{|l|}{ Mean Square } \\
\hline Confidence & $(F=1.624 ; P .167)$ & & & \\
\hline Inter Groups & 1.620 & 4 & .405 & \\
\hline Within Group & 106.222 & 426 & .249 & \\
\hline Total & 107.843 & 430 & & \\
\hline Control & $\left(\mathrm{F}=3.111 ; \mathrm{P}=.015^{*}\right)$ & & & \\
\hline Inter Groups & 6.473 & 4 & 1.618 & \\
\hline Within Group & 221.580 & 426 & .520 & $1>2$ \\
\hline Total & 228.054 & 430 & & \\
\hline Continuity & $(\mathrm{F}=891 ; \mathrm{P}=.469)$ & & & \\
\hline Inter Groups & .976 & 4 & .244 & \\
\hline Within Group & 116.627 & 426 & .274 & \\
\hline Total & 117.603 & 430 & & \\
\hline \multicolumn{5}{|c|}{ SMTQ General Average $(\mathrm{F}=1.842 ; \mathrm{P}=.120)$} \\
\hline Inter Groups & 1.238 & 4 & .309 & \\
\hline Within Group & 71.583 & 426 & .168 & \\
\hline Total & 72.821 & 430 & & \\
\hline
\end{tabular}

As the conclusion (Table I) of the applied ANOVA test. a statistically significant difference was determined between the leagues in control sub-dimension of the mental toughness concerning the league variable $(\mathrm{p}=0.015<0.05)$.
Ambient Science, 2021: Vol. 08(Sp1); 24-29 DOI:10.21276/ambi.2021.08.sp1.ta04

Table-2: ANOVA test results of mental toughness levels concerning the Club variable

\begin{tabular}{|c|c|c|c|c|}
\hline \multicolumn{5}{|c|}{ Mental toughness levels } \\
\hline Groups & Sum of Squares & df & \multicolumn{2}{|c|}{ Mean Square } \\
\hline Confidence & \multicolumn{4}{|l|}{$(\mathrm{F}=2.158 ; \mathrm{P}=.073)$} \\
\hline Inter Groups & 2.142 & 4 & \multicolumn{2}{|l|}{.535} \\
\hline Within Group & 105.701 & 426 & \multicolumn{2}{|l|}{.248} \\
\hline Total & 107.843 & 430 & & \\
\hline Control & \multicolumn{4}{|c|}{$\left(\mathrm{F}=2.709 ; \mathrm{P}=.030^{*}\right)$} \\
\hline Inter Groups & 5.658 & 4 & 1.414 & $4>1$ \\
\hline Within Group & 222.396 & \multicolumn{3}{|c|}{$426 \cdot 522$} \\
\hline Total & 228.054 & & \multicolumn{2}{|l|}{430} \\
\hline Continuity & \multicolumn{4}{|c|}{$\left(\mathrm{F}=4.754 ; \mathrm{P}=.001^{*}\right)$} \\
\hline Inter Groups & 5.025 & 4 & \multicolumn{2}{|l|}{1.256} \\
\hline Within Group & 112.578 & 426 & .264 & $4>1.2 .3$ \\
\hline Total & 117.603 & & \multicolumn{2}{|l|}{430} \\
\hline \multicolumn{5}{|c|}{ SMTQ General Average $\left(\mathrm{F}=4.472 ; \mathrm{P}=. \mathrm{ooz}^{*}\right)$} \\
\hline Inter Groups & 2.935 & 4 & .734 & \\
\hline Within Group & 69.886 & 426 & .164 & $4>1.3$ \\
\hline Total & 72.821 & & 430 & \\
\hline
\end{tabular}

As the conclusion (Table-2) of the applied ANOVA test, a statistically significant difference was determined in mental toughness general mean scores among the clubs in control and continuity sub-dimensions concerning the club variable. Tukey HSD and Tamhane tests were applied in order to detect the clubs having the difference, and it was detected that the difference was among TM Akhisarspor, Altay, Bali kesirsporBaltok and Grand Medical Manisaspor teams.

Table-3: ANOVA test results of mental toughness levels concerning the Position variable

\begin{tabular}{|c|c|c|c|}
\hline \multicolumn{4}{|c|}{ Mental toughness levels } \\
\hline Groups & Sum of Squares & df & Mean Square \\
\hline Confidence & \multicolumn{3}{|l|}{$(\mathrm{F}=1.077 ; \mathrm{P}=.375)$} \\
\hline Inter Groups & 1.619 & 6 & .270 \\
\hline Within Group & 106.224 & 424 & .251 \\
\hline Total & 107.843 & 430 & \\
\hline Control & \multicolumn{3}{|c|}{$(\mathrm{F}=1.374 ; \mathrm{P}=.224)$} \\
\hline Inter Groups & $4 \cdot 350$ & 6 & .725 \\
\hline Within Group & 223.704 & 424 & .528 \\
\hline Total & 228.054 & 430 & \\
\hline Continuity & \multicolumn{3}{|c|}{$(\mathrm{F}=.888 ; \mathrm{P}=.503)$} \\
\hline Inter Groups & 1.460 & 6 & .243 \\
\hline Within Group & 116.143 & 424 & .274 \\
\hline Total & 117.603 & 430 & \\
\hline \multicolumn{4}{|c|}{ SMTQ General Average $(\mathrm{F}=1.521 ; \mathrm{P} .170)$} \\
\hline Inter Groups & 1.534 & 6 & .256 \\
\hline Within Group & 71.287 & 424 & .168 \\
\hline Total & 72.821 & 430 & \\
\hline
\end{tabular}

1=Goalkeeper $2=$ Stopper $3=$ Back $4=$ Winger $5=$ Defensive Midfield $6=$ Offensive Midfield $7=$ Forward

As the conclusion (Table-3) of the applied ANOVA test, no statistically significant difference was determined in mental toughness general to mean scores between the positions in confidence, control, and continuity sub- 
dimensions concerning the position variable ( $p>0.05$ ).

Table-3: T-test results of the mental toughness levels concerning championship experience

\begin{tabular}{llllllll}
\hline \multicolumn{2}{l}{ Mental toughness levels } & & & & & \\
& Group & Df & Average & SD & DF & T & P \\
\hline Confidence & Yes & 86 & 3.2403 & .55342 & 429 & .451 & .652 \\
& No & 345 & 3.2130 & .48751 & & & \\
Control & Yes & 86 & 2.5058 & .86601 & 429 & 2.021 & $.046^{*}$ \\
& No & 345 & 2.3029 & .68512 & & & \\
& Yes & 86 & 3.4767 & .58237 & 429 & .229 & .819 \\
& No & 345 & 3.4623 & .50796 & & & \\
Continuity & Yes & 86 & 3.0980 & .50875 & 429 & 1.490 & .137 \\
& No & 345 & 3.0242 & .38294 & & & \\
\hline
\end{tabular}

The natural vegetation of Mt. Makiling Forest Reserve is dominated by many dipterocarp species. Though some of the original vegetation was selectively logged in the early 1940s (Luna et al., 1999), the forest reserve still holds a remarkable number of indigenous tree species (Fernando et al., 2008). Per inventory on the mixed forest plot, a total of 43 individuals belonging to 18 species, 18 genera and 12 families were recorded. Most trees were classified as large trees reaching $112 \mathrm{~cm}$ dbh and $37 \mathrm{~m}$ height. The plot, however, had a mean dbh of $20.7 \pm 6.6 \mathrm{~cm}$ and mean height $13.7 \pm 2.5 \mathrm{~m}$.

Discussion and Conclusion:

TIt is observed in the literature that previous studies were conducted on different fields of mental toughness. In a study on the relationship between mental toughness and optimal performance moods of players conducted by Crust \& Swann (2011), a positive and significant relationship was determined between mental toughness and optimal performance. Hodge et al., (2009) found a positive and significant relationship between the confidence subdimension of mental toughness and optimal performance mood. Hodge et al., (2009) also detected that commitment and struggling moods are the determinants of the optimal performance mood. Considering these research studies, which attempted to reveal the relation between mood and mental toughness, it is observed that the players with mental toughness are the ones, who can succeed in sustaining his/her concentration throughout the contest, focus his/her attention in case of a distraction, contestatory, unyielding in difficult situations, and turn the negativities into favorable opportunities. These findings are observed to be the studies that reveal the relationship between mental toughness and optimal mood (Crust \& Swann, 2011). In studies attempting to examine the relationship between mental toughness and motivation, it was determined that the players with higher intrinsic motivation had higher mental toughness levels (Gucciardi, 2010).

As the conclusion of the applied ANOVA test in Table II, a statistically significant difference was determined between the leagues in the control sub-dimension of the mental toughness concerning the league variable $(\mathrm{p}=0.015<0.05)$. In the Tamhane test, which was applied to detect the leagues having a difference, it was determined that the difference was between $\mathrm{U}_{14}$ and $\mathrm{U}_{15}$ leagues. It was determined that the mean mental toughness levels of football players of the U14 league were $($ mean=2,54) statistically significantly higher than that of the $\mathrm{U}_{15}$ league $($ mean $=2,14)$. No previous study was encountered in the literature conducted on determining the mental toughness levels based on the league variable in the football branch. However, in a study conducted on basketball players, no significant difference was determined among the players concerning their mental toughness levels based on league categories (Yazici, 2016). In a study on rugby players in different league categories conducted by Golby \& Sheard (2004), it was determined that there were small differences concerning negative energy and attention control among players playing in different leagues. In the study on elite and non-elite Korean women athletes of different leagues, Shin \& Lee (1994) determined that the mental toughness levels of elite athletes were higher. In our study, the motive behind the significant difference in the control sub-dimension of mental toughness based on league variable can be attributed to that the U-14 league is the first contest league. Since the players in the U-14 league are firstly playing in a league status, they feel themselves more comfortable, and this case helps their mental toughness levels sustain at high levels in terms of control sub-dimension. As the conclusion of the applied ANOVA test in Table II, a statistically significant difference was determined in mental toughness general to mean scores among the clubs in control/continuity sub-dimensions concerning the club variable $(\mathrm{p}<0.05)$. No previous study was encountered in the literature conducted on determining the mental toughness levels based on the team variable. The difference determined at the analysis between the teams concerning the control/continuity sub-dimensions can be attributed to the fluctuation in the yearly performances of the Grand Medical Manisaspor team and its effect on the players. That Grand Medical Manisaspor is making an effort to come up to the upper league after being dropped to the lower league can be attributed to that the players at the youth setup are not yielding in different situations and they have confidence in themselves. As the conclusion of the applied ANOVA test in Table Ill, no statistically significant difference was determined in mental toughness general to mean scores between the positions in confidence, control, and continuity sub-dimensions concerning the position variable ( $>>0.05)$. When the previous studies on mental toughness are examined, it is observed that there was no study based on position variables. As the conclusion of the applied t-test in Table $V$, a statistically significant difference was determined between the groups with championship 
TECHNOSCIENCE ARTICLE

experience and groups without championship experience in the control sub-dimension of the mental toughness levels concerning the championship experience variable $(\mathrm{p}=0.046<0.05)$. According to the control sub-dimension, the mean scores of the players with championship experience (mean $=2,50)$ were statistically significantly higher than that of $($ mean=2,30) players without championship experience. When the literature was examined; it was observed that there was a positive relationship between success and mental toughness (Loehr, 1986; Golby \& Sheard, 2004; Nicholls et al., 2008). Morgan (1980) defends that successful athletes have better mental health levels than unsuccessful ones. Thus, mental health is correlated with sportive success and performance. The athletes, who experienced championship, moved away from negative moods (tension, anger, exhaustion, etc.) and didn't yield in failures, becoming mentally more durable. Concerning the leagues of the players, it was determined that the mental toughness of the football players in the U14 League was higher compared to those of the $\mathrm{U}_{15}$ League for the control sub-dimension. Concerning the clubs of the football players, it was determined that the players of the Grand Medical Manisaspor team had statistically significantly higher scores in mean mental toughness and control/continuity sub-dimensions compared to the scores of the players in TM Akhisarspor, Altay, and Balýkesirspor Baltok teams. Examining the mental toughness level according to the position variable, it was determined that there was statistically no significant difference. When the influence of championship experience over mental toughness was examined, it was determined that the football players with championship experience had statistically significantly higher scores compared to those of the players without championship experience in the control sub-dimension of mental toughness.

\section{References:}

Beardslee, W.R. \& Podorefsky, M.A. (1998): Resilient adolescents whose parentshave serious affective and other psychiatric disorders: ýmportance of selfunderstanding and relationships. Am. J. Psychiatry, 145:63-69.

Block, J.H. \& Block, J. (1980): The role of ego-control and egoresiliency in theorganisation of behaviour (pp. 39-101). In: WA Collins (Ed.), Development of Cognition, Affect, and Social Relations: Minnesota Symposia on Child Psychology. Vol.-13. Pub. by: Psychology Press.

Bull, S.J., Albinson, J.G. \& Shambrook, C.J. (1996): The Mental Game Plan: Getting Psyched for Sport. Eastbourne: Sports Dynamics.

Bull, S.J., Shambrook, C.J., James, W. \& Brooks, J.E. (2005): Towards an understanding of mental toughness in elite English cricketers. J. App. Sport Psychol., 17:209-227.

Crust, L. (2008): A review and conceptual re-examination of mental toughness: Implications for future researchers. Person. Indiv. Diff., 45:576-583.
Ambient Science, 2021: Vol. 08(Sp1); 24-29 DOI:10.21276/ambi.2021.08.sp1.ta04

Crust, L. \& Swann, C. (2011): Comparing two measures of mental toughness. Personality and Individual Differences, 50:217-221.

Clough, P.Ý., Earle, K. \& Sewell, D. (2002): Mental toughness: the concept and itsmeasurement. In I. Cockerill (Ed.), Solutions in Sport Psychology London: Thomson Publishing, :32-43.

Connaughton, D., Wadey, R., Hanton, S. \& Jones, G. (2008): The development and maintenance of mental toughness: Perceptions of elite performers. J. Sports Sci., 26:8395.

Connaughton, D., Hanton, S. \& Jones, G. (2010): The development and maintenance of mental tougness in the world's best performers. The Sport Psychologist, 24:168-193.

Connaughton, D., Thelwell, R. \& Hanton, S. (2011): Mental toughness development: ýssues, practical implications and future directions. In D.Gucciardi and S. Gordon (Eds.). Mnetal toughness in sport: developments in theory and research (pp. 135-162). New York: Routledge.

Doðan, O. (2015): Spor Psikolojisi. 3. Edition, Ankara: Detay Publishing House.

Durdubao, D. (2015): Psikolojik Beceri Antrenmanýna Girip " Spor ve Egzersiz Psikolojisinin Temelleri". :247-271 (Editörler; Pahin M, KoruçZ).

Garmezy, N. (1991): Resilience and vulnerability to adverse developmental outcomes associated with poverty. Am. Behav. Scientist, 34:416-430

Golby, J. \& Sheard, M. (2004): Mental toughness and hardiness at different levels of rugby league. Personality and Individual Differences, 37:933942.

Golby, J., Sheard, M. \& Lavallee, D. (2003): A cognitive behavioural analysis of mental toughness in national rugby league teams. Perceptual and Motor Skills, 96:455-462.

Goldberg, A.S. (1998): Sports Slump Busting: 1o Steps to Mental Toughness and Peak Performance. Champaign, IL: Human Kinetics.

Gould, D., Hodge, K., Peterson, K. \& Petlichkoff, L. (1987): Psychological foundations of coaching: Similarities and differences among intercollegiate wrestling coaches. The Sport Psychologist, 1:293-308.

Gucciardi, D.F. (2010): Mental toughness profiles and their relations with achievement goals and sport motivation in adolescent Australian footballers. J. Sports Sci., 28(6):615-625.

Harmison, R. (2011): A social-cocgnitive framework for understanding and developing mental toughness in sport. In D.Gucciardi and S.Gordon (Eds.), Mental tougness in sport: Developments in theory and research (pp. 47-68). New York: Routledge.

Hodge, K., Lonsdale, C. \& Jackson, S. (2009): Athlete teen engagement in elite sport: An exploratory investigation of antecedents and consequence. The Sport Psychologist, 23:186202.

Jacelon, C.S. (1997): The trait and process of resilience. L. Advanced Nursing, 25:123-129.

Jackson, S., Thomas, P., Marsh, H. \& Smethurst, C. (2001): Relationships between flow, self-concept psychological skills, and performance. J. Appl. Sport Psychol., 13:129-153.

Jones, G., Hanton, S. \& Connaughton, D. (2002): What is this thing called mental toughness? An investigation of elite sport 
performers. J. Appl. Sport Psychol., 14:205-218.

Jones, G., Hanton, S. \& Connaughton, D. (2007): A framework of mental toughnessin the world's best performers. Sport Psychol., 21:243-264.

Jones, M.I. \& Parker, J.K. (2013): What is the size of the relationship between global mental toughness and youth experiences? Person. Indiv. Diff., 54:519-523.

Ilkim, M., Canpolat, B. \& Akyol, B. (2018): The Effects of Eight-Week Regular Training in Amateur Amputee Football Team Athletes' Body Composition. Turk. J. Sport Exer., 20(3):199-206

Inal, A.I. (2004): "Futbolda Egitim Ögretim” Pub. by: Nobel Publishing House, Ankara, Turkey.

Luthans, F. (2002): Positive organizational behavior: Developing and managing psychological strengths. Acad. Manag. Exe., 16(1):5772.

Luthar, S.S., Cichetti, D. \& Becker, B. (2000): The construct of resilience: A critical evaluation and guidelines for future work. Child Dev., 71:543-562.

Maddi, S.R. \& Khoshaba, D.M. (1994): Hardiness and mental health. L. Person. Asses., 63(2):265-274.

Masten, A.S. (2001): Ordinary magic: Resilience processes in development. Am. Psychol., 56:227-238.

Masten, A.S., Best, K.M. \& Garmezy, N. (1990): Resilience and development: Contributions from the study of children who overcome adversity. Devel. Psychopathol., 2:425-444.

Morgan, W.P. (1980): The trait psychology controversy. Res. Quart. Exer. Sport, 51:50-76.

Nicholls, A.R., Polman, C.J., Levy, A.R. \& Backhouse, S.H. (2008): Mental toughness, optimism, and coping among athletes. Personal. Indiv.Differ., 44:1182-1192.
Klag, S. \& Bradley, G. (2004): The role of hardiness in stress and illness: An exploration of the effect of negative affectivity and gender. Br. J. Health Psychol., 9:137-161.

Loehr, J.E. (1986): Mental toughness training for sports: Achieving athletic excellence. Pub. by: Stephen Greene Press, Lexington, MA.

Loehr, J.E. (1995): The New Mental Toughness Training for Sports. Pub. by: Plume.

Sheard, M. (2013): Mental Toughness: The Mindset Behind Sporting Achievement. Second Edition. Pub. by: Routledge, New York.

Shin, D.S. \& Lee, K.H. (1994): A comparative study of mental toughness between elite and non-elite female athletes. Kor. J. Sport Sci., 6:85102.

Thelwell, R., Weston, N. \& Greenlees, I. (2005): Defining and understanding mental toughness within soccer. J. Appl. Sport Psychol., 17:326-332.

Toprakkaya, I. \& Tekin, T.A. (2004): Futbol Genel Kuramsal Bir Çerçeve ve Teknik ve Temel Taktik Ögretim. Pub. by: Nobel Publishing House, Ankara.

Werner, E.E. (1995): Resilience in development. Current Direct. Psychol. Sci., 4:81-85.

Williams, R.M. (1988): The U.S. Open character test: Good strokes help. But the most individualistic of sports is ultimately a mental game. Psychol. Today, 22:60-62.

Yazici, A. (2016): Mental toughness and emotional intelligence of professional basketball players in terms of different variables. Gazi Uni. Inst. Health Sci., M. Sc. Thesis. 